\title{
In memoriam prof. dr. P. J. Kuijjer
}

Op 13 juli 2002 overleed prof. dr. P.J. Kuijjer in zijn woonplaats Haren. Professor Kuijjer was van 1966 tot 1986 hoogleraar heelkunde aan de Rijksuniversiteit te Groningen, waar hij een belangrijke rol heeft gespeeld in het medisch opleidingscontinuüm.

Pieter Jan Kuijjer werd geboren op 7 april 1921 te Amsterdam. Na het behalen van het gymnasium bèta diploma studeerde hij geneeskunde te Leiden en Amsterdam. Op 17 januari 1947 werd hij te Leiden bevorderd tot arts, waarna hij in de daaropvolgende twee jaren assistent was in de pathologische anatomie bij prof. dr. H.T. Deelman in Amsterdam. Daar promoveerde hij op 1 juli 1948 op een proefschrift getiteld: 'De ontwikkeling van het begrip tuberkel'. Na het vervullen van de militaire dienstplicht werd hij opgeleid tot chirurg (1950-1957) in het Wilhelminagasthuis te Amsterdam onder leiding van prof. dr. I. Boerema. Nadien was hij hoofd van een der chirurgische afdelingen van het Gemeenteziekenhuis aan de Zuidwal te 's-Gravenhage van 1957 tot 1966.

In 1966 volgde hij prof. dr. L.D. Eerland op als hoogleraar-directeur van de Chirurgische Universiteitskliniek te Groningen. Onder diens leiding was de Groningse kliniek tot een ongekende hoogte en omvang gebracht. Het is onder meer de verdienste van Kuijjer geweest dat de onderafdelingen zich verder konden ontplooien en dat ruimte werd gecreëerd voor nieuwe ontwikkelingen als de transplantatiechirurgie (hetgeen erin resulteerde dat de eerste levertransplantatie in Nederland in 1979 in Groningen plaatsvond), de traumatologie en de chirurgische oncologie.

De chirurgische kliniek bestond in die tijd niet alleen uit de heelkunde, maar ook uit thoraxchirurgie, orthopedie, urologie en plastische chirurgie. Kuijjer was van mening dat onderwijs onlosmakelijk onderdeel van het klinisch bedrijf diende te zijn en hij droeg die mening uit in de praktijk door zijn stafleden nauw bij het begeleiden van co-assistenten en assistenten te betrekken. Hij legde zelf altijd veel nadruk op de basistechnieken van anamnese, onderzoek en verslaglegging. Vanuit de overtuiging dat je van onderwijs geven zelf het meeste leert, liet hij de assistenten lessen verzorgen voor de inserviceopleiding van verpleegkundigen.

Een van zijn eerste publicaties op dit gebied betrof het boek: 'Inleiding tot de chirurgie' (1968) in de serie 'In goede handen', een leergang voor verpleegkundigen. Dit boek was destijds zeer geliefd studiemateriaal voor studenten geneeskunde, die hierin in zeer begrijpelijke taal vele chirurgische ziektebeelden uitgelegd kregen (wat is het verschil tussen een wond en een zweer?). Nadien (1971) verscheen 'Chirurgisch onderzoek', het beroemde groene boekje, dat je als co-assistent in de zak van de witte jas kon meenemen. Beide boeken kenden vele drukken. Hij was een van de redacteuren van de eerste druk van het 'Leerboek Chirurgie', dat in 1983 verscheen en waaraan door hoogleraren van alle medische faculteiten werd bijgedragen.

De opleiding chirurgie te Groningen werd door hem grondig gereorganiseerd. 
Iedere drie maanden werd een stage in een van de onderafdelingen van de heelkunde of in een van de chirurgische specialismen gevolgd. De volgorde stond vast. Het was voor assistenten en stafleden vooraf duidelijk wie welke ingrepen in welke stage mocht verrichten. De begrippen opleidingsplan, structuur en leerdoelen, die de lezers van dit tijdschrift hiervoor zouden gebruiken, waren toen in de geneeskundeopleiding nog onbekend. Elke assistent kan zich het vooropereren door Kuijjer en het door hem gecoacht worden nog scherp herinneren: streng, rechtvaardig, consequent en met weinig woorden.

Op landelijk niveau bekleedde hij vele bestuursfuncties en droeg hij in hoge mate bij tot de totstandkoming van de 'basiscursus', een cursus voor de eerste twee opleidingsjaren van de snijdende specialismen. Kuijjer was ook geïnteresseerd in nascholing. Hij organiseerde met de voltallige staf de zogenaamde 'Chirurgencursussen'. Gedurende een week werd door bezoekende chirurgen 's ochtends meegeopereerd en werden 's middags capita selecta over de nieuwste ontwikkelingen gegeven.

Kuijjer was een van de eerste afdelingshoofden die het belang zagen van het benoemen van een arts-onderwijscoördinator die behulpzaam was bij de voorbereiding van de colleges en de tentamens en bij de begeleiding van studenten tijdens de co-assistentschappen. De eerste drie onderwijscoördinatoren vervulden de functie tijdelijk. In die tijd werd de cursus chirurgische diagnostiek ingevoerd als vervanging van het junior co-assistentschap. Samen met de cursus bij de obstetrie/gynaecologie was dit de voorloper van de latere facultaire introductiecursus klinische vaardigheden. Kuijjer schreef indertijd in een personeelsdossier dat de functie tijdelijk ingevuld moest worden, omdat er anders onvoldoende nieuwe ontwikkelingen plaats zouden vinden. Zoals bij veel onderwerpen was Kuijjer ook hier bereid zijn mening te herzien: de volgende onderwijscoördinatoren vervulden hun functie langere tijd. Kuijjer ondersteunde nieuwe ontwikkelingen door zelf het goede voorbeeld te geven. Nadat was aangetoond dat het traditionele artsexamen niet erg betrouwbaar was, observeerde hij mee achter het one-way-screen met behulp van een checklist. Ook was hij een van de eerste observatoren van het stationsexamen na afloop van de introductiecursus. Tegen de stafleden was hij hierover duidelijk: "Alleen als wij op deze wijze examineren, kunnen we een betrouwbaar oordeel vellen". Hij was zeer geïnteresseerd in de kwaliteit van toetsvragen en verzamelde op de hem zo kenmerkende zorgvuldige wijze de p-waarden van de meerkeuzevragen.

$\mathrm{Na}$ zijn pensionering in 1986 kon hij zich aan zijn andere interesses wijden: paardrijden, Franse literatuur en de geschiedenis van de geneeskunde. Hij was een der oprichters van de Petrus Camper Stichting, een platform voor de bevordering en beoefening van de geschiedenis van de geneeskunde. Zo verzorgde hij jarenlang de lunchcolleges, met lichtbeelden: 'Uit de geschiedenis van de geneeskunde en de verpleging' en publiceerde hij in 1993 het boek 'Kloppen en luisteren, uit de geschiedenis van de percussie en auscultatie'.

Kuijjer heeft zich als opleider aanvankelijk laten zien als een streng leermeester (een gaasje tijdens de operatie los op de buik betekende een week operatieverbod; vijf minuten te laat op de operatiekamer betekende zelfs voor de hoofdassistent dat Kuijjer de operatie overnam), bij wie men wel degelijk wist waar men aan toe was. 
Als assistent was je meneer, als specialist dokter en alleen hoogleraren was het toegestaan hem te tutoyeren. In de kliniek gaf hij steeds het goede voorbeeld, door het zelf (model)statussen van zijn klassepatiënten en door zijn zeer correcte houding jegens patiënten en verpleging. Tegelijkertijd verstond hij de kunst om zich kwetsbaar op te stellen door openlijk zijn eigen complicaties ter sprake te brengen tijdens patiëntenbesprekingen en daaruit lering te trekken. In het Nederlands Tijdschrift voor Geneeskunde bepleitte hij het zo open mogelijk bespreken van complicaties.

In de latere jaren ontpopte hij zich als een beminnelijk mens. Vele oud-leerlingen (van hen zijn er veertien hoogleraar geworden) hebben het genoegen gehad om bij hem en zijn echtgenote herinneringen op te halen en over de rol van de geneeskunde in de maatschappij te discussiëren.

Kuijjer was een erudiet man, die in de jaren zestig en zeventig ontegenzeggelijk een stempel heeft gedrukt op een aantal gebieden van het medisch opleidingscontinuüm, voor velen een rolmodel, aan wie wij met respect terugdenken.

\section{R.P. Zwierstra}

A.J.J.A. Scherpbier 